\title{
Students' Vocabulary Mastery through Word Wall at SMPN 44 Surabaya
}

\author{
Siti Fatimah \\ SMPN 44 Surabaya, email: fatimah250276@gmail.com
}

\begin{abstract}
The aim of this research was to find out how far the Word Wall to improve students' vocabulary mastery at SMPN 44 Surabaya. Classroom action research was applied to the 40 students of the class 7-D as the subjects of this research. In applying the Word Wall, there were two cycles applied consisting of three meetings for each cycle. The researcher used the students' tests result to measure the improvement of their vocabulary achievement. The results of this research showed the increasing students' vocabulary mastery proven by the results of the tests conducted. Mean of the pre-test was 50 and mean of the post-test in cycle I was increased becoming 70 . Then, mean of post-test in cycle II was significantly improved in 93 . The research was stopped in the cycle II in regard of the criteria of success was $82.5 \%$. The researcher found out there were a significant students' vocabulary mastery after implementing the Word Wall. it is recommended English teachers who teach vocabularies should apply the Word Wall Strategy regarding can help students easily to understand the content of the texts. For the students, they can use and have more exercises with the Word Wall to enrich their vocabularies in daily activities. For other researchers, it is suggested to conduct the similar research by exploring the areas of focus in other English skills.
\end{abstract}

Keywords: vocabulary, vocabulary mastery, word wall

\section{INTRODUCTION}

Vocabulary is the assortment of words that an individual knows through languages used. Vocabulary, one of the important components of languages, becomes a basic component in learning English and has a primary role affecting the four language skills: listening, speaking, reading and writing (Anggraini, 2018, p. 1). Students might determinate in understanding the reading text, they can write, and they can speak a language when they can master of vocabulary as well. The students who do not master a sufficient number of vocabularies might fail in using language either in oral or written form. It is clear vocabulary is the essential component to be mastered regarding its role.

One of the English skills as well as language element such as vocabulary must be taught to the students in all levels. David Nunan argues the acquisition of an acceptable vocabulary is a basic for making a good language use since without extensive vocabulary, individual will be uncapable to use structure and function they may have learned for comprehensible toward 
communication (Nunan, 2003, p. 125). It forms an important component in learning English where the vocabulary mastery will affect someone's ability in using the language either in spoken or written form. In listening skill, to be able to understand someone utterance, people should know what the meaning of words and sentences being said. Consequently, they know the intention of the utterance and are able to respond either through action or react it using verbal utterance, which here, they have to use words to do. Moreover, to be able to understand what people is reading, they should be able to understand the meaning that is being conveyed through the written words. In short, it is imperative for the learners to have adequate vocabulary in order to communicate well.

In educational field, teaching vocabulary is one of many ways to improve English competence of the students who are learning English. Teaching vocabulary is such an important task in teaching English because vocabulary achievement is related to all language learning and it is of concern to all four language skills (Anggraini, 2018). Since, vocabulary is one of language elements and significant for the students particularly for beginners, vocabulary mastery is the ability to learn English. If they master vocabulary, they are going to be easy to understand the written material. In fact, the complications in learning English include the characteristic of the vocabulary itself. The students' difficult to remember the word, to spell, and to understand the meaning of the word they got. Subsequently, the students must be aware of the vocabularies. The students also have lack of interest in learning English and they need a media to improve their interest.

As a matter of fact, the researcher assumed the students' learning vocabulary development, especially junior high school students, is somewhat causing uneasiness. Based on the preliminary research conducted on November $20^{\text {th }}, 2020$ to the class 7-D of SMPN 44 Surabaya within virtual classroom, the researcher found the students' vocabulary mastery was still low. It was proved by the achievement of students' test were lower than the Minimum Mastery Criteria $(K K M)$ of English subject in the $7^{\text {th }}$ graders of SMPN 44 Surabaya is 75. Considering the problem above, the researcher, as an English teacher, must have to work hard to solve the problem due to the teacher is an important factor in language learning that should be able to use several ways or tools of teaching which can make students more interest in learning English such as providing a media of learning. Then, the vocabulary might be mastered through the process of teaching and learning, and the result of learning depends on the process that build up the students' interest through a media applied as a solution in solving the problem. 
A media is tool which is prepared and brought into classroom by a teacher to facilitate teaching-learning activity where it can get instruction and stimulates students to learn as its implementation. Therefore, teaching media are projected to help teacher in presenting the lesson more clearly and interesting to be followed by the students (Reiser, 1996, p. 68). Gunning (2000) suggested creating an interesting atmosphere of word learning can have a substantial impact upon development of students. Consequently, the researcher tried to overcome the problems above by applying "Word Wall" as a media of learning to increase the students' vocabulary mastery.

Erin (2011) states interactive words walls showcase well-selected words that can assist teachers to build a foundation for student content vocabulary comprehension. Word wall also support word-learning strategies by highlighting such as root words, suffixes, prefixes, and their meanings so that can help students decode meaning in text. Moreover, when students use the word walls, they become more conscious of words and definitions. This support content comprehension. It also helps students become aware of vocabulary in the world around them. Additionally, Cleaver (2018) argued "A word wall, one of media online learning, is a wall devoted to displaying high frequency words (these could be sight words or words that are used a lot in class) that are important for students to know and use in which these are words where students can learn to read and write." In upper grade classrooms, these can be words related to concepts and topics that students are learning about.

The researcher focused the research on the effectiveness of the Word Wall media online learning to improve students' vocabulary mastery in learning English. Hence, in this research, the researcher used the Word Wall to teach vocabulary mastery at the $7^{\text {th }}$ grade students of SMPN 44 Surabaya. related to the background mentioned, the researcher decided to conduct the research entitled: "Students' Vocabulary Mastery through Word Wall at SMPN 44 Surabaya" by the aim to describe the effectiveness of the Word Wall media to improve students' vocabulary mastery in learning English at the class 7-D of SMPN 44 Surabaya in the academic year 2020/201.

\section{LITERATURE REVIEW}

\section{Vocabulary}

Vocabulary is a basic element of language that is important to gain the meaning of word s. According to Richards \& Renandya (2002, p. 255), vocabulary is a core component 
of language proficiency and provides much of the basis for how well learners speak, listen, read, and write. It is implied vocabulary becoming one of the important parts in learning English, particularly in reading comprehension, especially for the beginners. The main reason for these namely: firstly, vocabulary is used as the main tool to understand forms, phrases, sentences and texts in one or more paragraphs; secondly, it functions to convey the meaning of the words in a text.

Additionally, vocabulary refers to words we use to communicate in oral and print language (Hanson \& Padua, 2011, p. 5). In other word, vocabulary is a list of words which have to learn by people to express their feeling and ideas. Oral vocabulary is the set of words for which we know the meanings when we speak or read orally. Print vocabulary consists of those words for which the meaning is known when people write or read silently. From the definitions above, it can be concluded vocabulary is list of word as well as word meanings that people use and understood, in both oral and written language.

\section{Vocabulary Mastery}

The mastery of vocabulary is inseparable with understanding about word classes. They are function and content words. These are essential elements that must be possessed by the learners, in order to, enable them to know and differentiate each it. Since vocabulary is one components of language and very important for the students especially for beginners, vocabulary mastery is the knowledge based on learn English. If the students have limited vocabulary, they feel hard to understanding text. If the students understanding vocabulary mastery can be easy to know of matters. Vocabulary is study to knowled ge of meaning and words regarding to how to pronunciation of word and how word used on context (Nation \& Newton, 1997, p. 82).

The acquisition of ad equate vocabulary is essential for successful foreign language use, because without an extensive vocabulary, people will be unable to use structural and function words that we have learned for comprehensible communication (Nunan, 1991, p. 125). Additionally, it obviously informs that both structural and function word acquisition give valuable contribution to comprehensible communication that will be a consideration at the end of teaching and learning process. Some people have passive vocabulary (word they understood) of up to 10.000 words, but an active vocabulary of between 10.000 and 20.000 words, it is for native speakers of a language. In foreign learning, an active vocabulary of about 3.000 to 5.000 words, and a passive vocabulary about 5.000 to 10.000 
words is regarded as the intermediate to upper intermediate level of proficiency. Meaning that, vocabulary mastery refers to the great knowledge of word sor the gaining of great skill in vocabulary.

\section{Word Wall}

A word wall, a platform online application, is a wall to display high frequency words that could be sight words or words that are used a lot in class. Word Wall can be used to create both interactive and printable activities. Most of templates are available in both an interactive and a printable version. Interactives are played on any web-enabled device, like a computer, tablet, phone or interactive whiteboard. They can be played individually by students or be teacher-led with students taking turns at the front of the class. Printable can printed out directly or downloaded as a PDF file that can be used as a companion to the interactive or as stand-alone activities (Wordwall Create better lessons quicker, n.d.). Word walls are important for young readers because they provide a place to post high frequency words that have already been taught. Thus, students can use the words as a reference during reading and writing, making them more independent while teaching them how to use a reference tool. Furthermore, word wall helps students see patterns and differences in words and recognize the similarities and differences between each word.

\section{METHOD}

\section{Research Design}

The research method used in this research was Classroom Action Research (CAR) due to the aim of this research to describe the effectiveness of the Word Wall media to improve students' vocabulary mastery in learning English at the $7^{\text {th }}$ grade students of SMPN 44 Surabaya in the academic year 2020/201 . According to Kumar, action research is a research method which is aimed for improving and modifying the working system of a classroom in school or institution provides the opportunity for educators or teachers to reflect their own practices (Singh, 2006, p. 577). Related to the definition mentioned, it is clear this research belongs to CAR due to classroom action research is inquiry or research which enables teachers or practitioners to investigate and evaluate their work in the classroom which is concerned for problem solving to improve teaching and learning in the classroom through self-reflection which is carried out with planned and systematic action. 
Before doing the real action, the researcher, as an English teacher, designed the lesson plan which was made in order to help the teacher to identify the students' need, preference, and also to motivate them to learn. The lesson plan was arranged and develop on the basis of the first semester program. It covered topic to be taught, the objectives, the steps of the teaching and learning process, and the media used. The action was implemented in two cycles involving the planning, observing, evaluating and reflecting, which consisted of 6 meetings held on November $2^{\text {nd }}, 2020$ to November $20^{\text {th }}, 2020$. In the first cycle, three meetings are provided for applying the Word Wall, while for the second cycle was applied three meetings.

\section{Research Subjects}

The subjects of this research were the first semester students of the class 7-D of SMPN 44 Surabaya consisting 40 students. The researcher chose this class due to this class had the low score in English subject especially in vocabulary mastery.

\section{Data}

The sources of data were all of students and teacher activity during the implementation of the Word Wall through teaching vocabulary for the subjects chosen. The students' results of the test in pre-test and post-test were the data of the study.

\section{Instrument}

The instrument of the research is tests called pretest and posttest. The type of test is objective test. The test is a multiple choice and matching test using the Word Wall media.

\section{Data Collection Procedures}

The researcher gave pre-test for the students in the first meeting to know the ability of the students' capability of mastering vocabulary to the topic being implemented. Meanwhile, the posttest was given after the students got the treatment on the implementation of the Word Wall to improve vocabulary mastery. In collecting the required data in the test, the researcher gave 10 questions in the form multiple choices. In a short, it is applied there were pretest, posttest in cycle I, and posttest in Cycle II. The results of the tests were analyzed with the criteria of success to know whether the students' skill in vocabulary improved. 


\section{Data Analysis}

Data analysis took from the average score of the pretest and posttest in cycle 1 and cycle 2 . The formula to get the average score in analyzing the datawas supported by theory form Ary, Jacobs \& Razavieeh (2007). Furthermore, to know the results based on the data examined, the researcher compared the average scores between pretest and posttest for each cycle. Then to know the percentage of increasing score in students learning activities, the researcher used the percentage formula. This research would success or finish if $75 \%$ of students got score minimum 75 and there was significant improvement in the students learning activity which occur until the last cycle.

\section{RESULTS FINDINGS AND DISCUSSION}

Before doing his research, the writer gave a general test which is called pre-test. The test consists of some adjectives and antonyms. The researcher as an English teacher wanted to measure how far the students in the class 7-D of SMPN 44 Surabaya understanding the words through the topic being discussed. She provided content materials of adjectives and antonyms consisted of 10 questions. The result of the pre-test was provided in the table. 1 and figure. 1 below:

Table. 1 Result of Pre-test

\begin{tabular}{|c|c|c|c|}
\hline \multicolumn{4}{|c|}{ Result of Pre-Test } \\
\hline Mean & The highest score & The lowest score & Success \\
\hline 60 & 80 & 50 & 4 \\
\hline
\end{tabular}

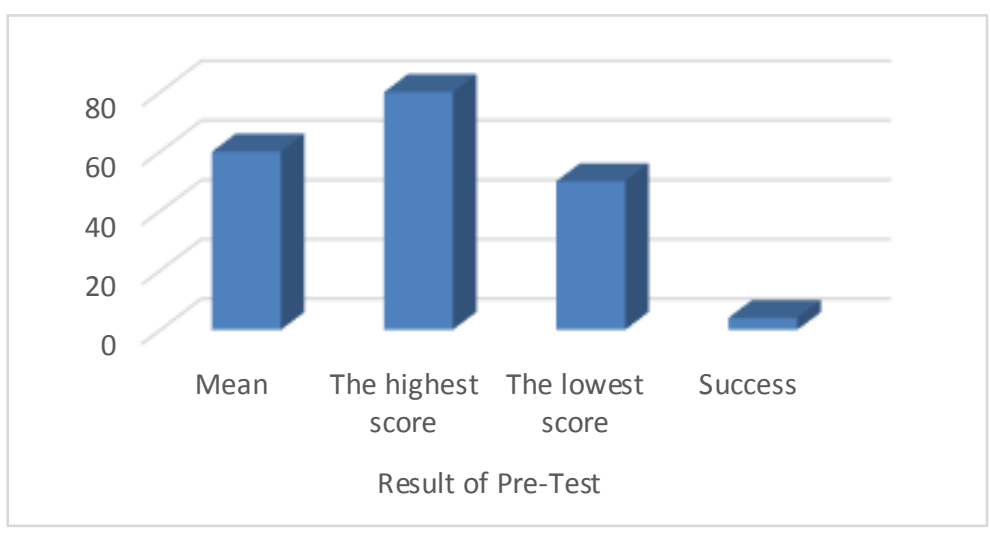

Figure. 1 Result of Pre-test 
The result showed that the students were under the average level. Four students were passed the test based on the standard of the research. Thus, the total numbers of students succeeded were $10 \%$. The highest score could reach 80 and the lowest one was 50 while the mean of the pre-test was 60. It could argue that this class needed to get a strategy in comprehending their vocabulary. Seeing that fact, the researcher provided the strategy to solve the problem. She then decided to choose a suitable approach inn teaching and learning activities during online classroom namely "Word Wall strategy". Aftergetting this strategy to be applied, the researcher tried to design lesson plans, English materials and evaluation tools in the planning. She planned to do two cycles in this research. But she didn't limit the research to the next cycle if it has failed in the last cycle (2 Cycle). Each cycle in this research consisted of three meetings and the last meeting be the test to measure the students comprehending about vocabulary through adjectives and antonyms as the topic being discussed at the time research conducted.

Then, the researcher started the research in cycle one on November $2^{\text {nd }}, 2020$. Three meetings had done successfully for Word wall strategy, and then she did post-test of November $9^{\text {th }}, 2020$, as the post-test of cycle I. She still used the same materials but different in the content of the lesson given. After doing the evaluation of the results of the test in the first cycle then compared to the results of pre-test through the result as shown in the following table. 2 and figure. 2 as follow:

Table. 2 Test Results

\begin{tabular}{|l|c|c|}
\hline \multicolumn{3}{|c|}{ Test Results } \\
\hline \multicolumn{1}{|c|}{ Categories } & Pre-test & Post-test Cycle I \\
\hline Mean & 60 & 70 \\
\hline The highest score & 80 & 80 \\
\hline The lowest score & 50 & 60 \\
\hline Success & 4 & 20 \\
\hline
\end{tabular}




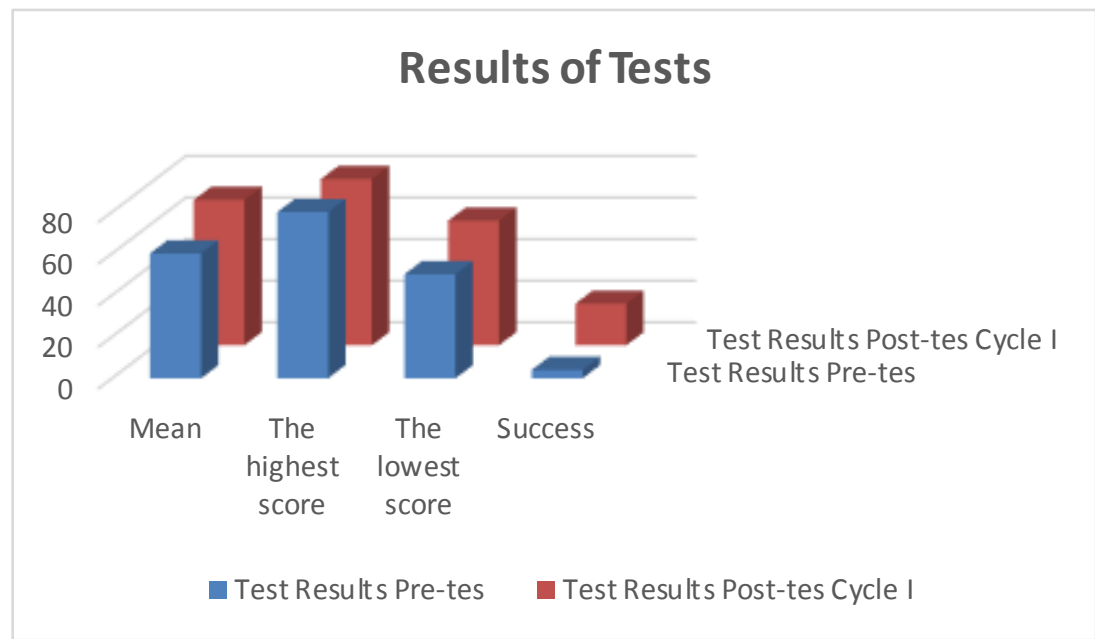

Figure.2 Results of Tests

From the data above, it can be argued that it needed to do the next cycle because the Word Wall strategy on the first cycle couldn't reach the minimum standard success of the research where due to the mean of the students' achievement in mastery of vocabulary was 70 and the total percentage of students' success was still $50 \%$. As the realty shown in the data above was the mean in the Word Wall Strategy was still 70, the highest score was 80 and the lowest one was 60 . The percentage of students' success was $50 \%$. But, if it is compared to the results of the pre-test, the improvements toward the students' mastery in vocabulary were improved in matter of mean's results from 60 to 70 , the highest score was still 80 and the lowest score was from 50 to 60 . Meanwhile, the numbers of students who passed the test were improving from 4 students to 20 students. It can be said that the numbers of students increased 16 students in the percentage of $40 \%$. Related to the results of the cycle I, the researcher needed to continue the next cycle to make this research would be success.

Before starting the next cycle (cycle II), the researcher did the reflecting in case of evaluation what was done in the previous cycle in order to resolve about the strengthen and the weakness of the Word Wall as its implementation. During the first cycle, she found (1) the Word Wall was new to the students so, they were confused for the first time during the implementation. For the next meeting, the students were serious and familiar with the Word Wall in learning activities; (2) the vocabularies in the texts given during the explanations could be understood faster because they had background knowled ge with them. Consequently, when they did the tasks, some of them did not need to look for the meaning in the dictionaries. As this strategy helped them much; (3) the students were happy doing their tasks. As they did competition one another to prove that they could handle their problems. Occasionally they got 
difficult and needed the teacher to explain a little to lead them understanding the concept of the materials. Then, the cycle II was done starting on November $13^{\text {th }}, 2020$ to November $20^{\text {th }}, 2020$. The researcher conducted the post-test in the cycle II on November $18^{\text {th }}, 2020$. The pot-test of cycle II was done after the implementation of the Word Wall in learning activities toward the teaching vocabulary topic specifically in the adjectives and antonyms. The results of the posttest in cycle II were presented in the following table. 3 and figure. 3 as below.

Table. 3 Test Results of the Word Wall

\begin{tabular}{|l|c|c|c|}
\hline \multicolumn{4}{|c|}{ Test Results } \\
\hline \multicolumn{1}{|c|}{ Categories } & Pre-test & Post-test Cycle I & Post-test Cycle II \\
\hline Mean & 60 & 70 & 93 \\
\hline The highest score & 80 & 80 & 100 \\
\hline The lowest score & 50 & 60 & 70 \\
\hline Success & 4 & 20 & 33 \\
\hline
\end{tabular}

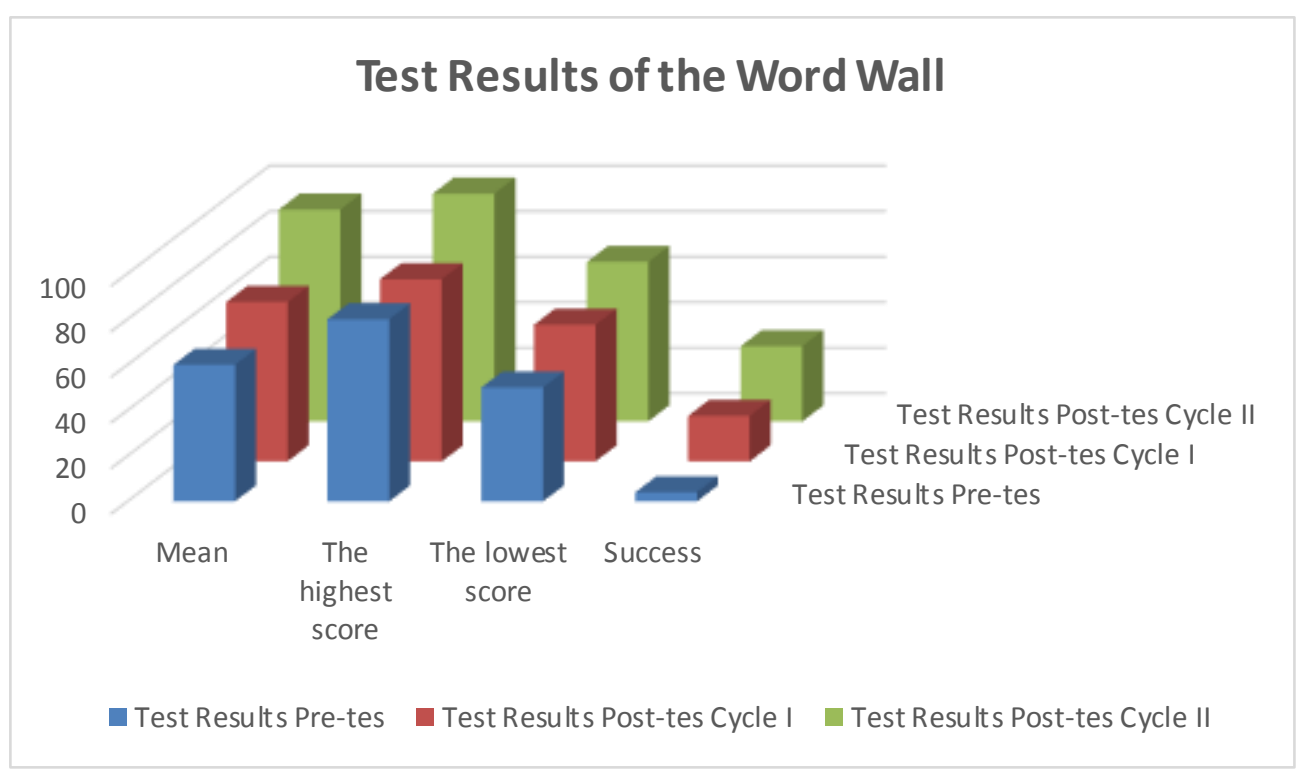

The table. 3 and figure. 3 showed there was a significant improvement in the results of the post-test in cycle II. The mean score in the implementation of the Word Wall was 93. The highest score of was 100. For the lowest score was 70. Meanwhile, the numbers of students who passed the post-test in the cycle II were 33 students in the percentage of success $82.5 \%$. there were still seven students were failed. From the results of the tests mentioned, the researcher concluded the research done would be stopped because the criteria of success had already reached in the percentage of $82.5 \%$. It is argued the implementation of the Word Wall could improve students' vocabulary mastery to the first 
semester students in class 7-D at SMPN 44 Surabaya in the academic year 2020/2021. It was obviously seen that the score of the students in vocabulary kept increasing from the pre-test until the post-test of cycle II. It was proved by the data which showed the mean of the students in the post-test cycle II when it was compared to the pre-test and post-test in the cycle I where the results of the students were 50 and 60. Overall, it is concluded the implementation of the Word Wall was very helpful in improving students' vocabulary mastery.

\section{CONCLUSION}

Based on the research findings, the conclusion can be drawn as follow: (1), the implementation of the Word Wall had positive impact on the improvement students' vocabulary mastery and also produced students' interest in learning process especially during online learning; (2) from the observation and documentation, the researcher argued the students did all of the stages in the teaching and learning process starting from preparing lesson plans to do pre-activities, whilst-activities and post activities well. The results of the implementation of the Word Wall in pre-test, post-test cycle I and post-test cycle II improved significantly. In the pre-test, mean of the test was 60 , the highest score was 80 , the lowest score was 50 and the students who passed the test was only 4 . Then, the results of the post-test in cycle II, mean of the test was 70, the highest score was 80 , the lowest score was 60 and the students who passed the test was still 20. Finally, the results of post-test in cycle II, mean of the test was significantly increased in 93, the highest score was 100, the lowest score was 70 and the students who passed the test was 33 students and still had 7 students who did not pass the test. The research was stopped in the cycle II in regard of the criteria of success was $82.5 \%$.

Based on the above conclusions, it is recommended English teachers who teach vocabularies should apply the Word Wall Strategy regarding can help students easily to understand the content of the texts. For the students, they can use and have more exercises with the Word Wall to enrich their vocabularies in daily activities. For other researchers, it is suggested to conduct the similar research by exploring the areas of focus in other English skills. 


\section{REFERENCES}

Anggraini, T. (2018). The Use of Word Walls Media to Improve Students' Vocabulary Mastery at the Eighth Grades of SMP Negeri 10 Metro. Metro, Lampung: An Undergraduate Thesis: The State Institute for Islamic Studies of Metro.

Ary, D., Jacobs, L., \& Razavieeh, A. (2007). Introduction to Research in Education (2nd Edition). New York: Holt Renehart and Winston.

Cleaver, S. (2018, June 27). What is a Word Wall? Retrieved November 30, 2020, from https://www.weareteachers.com/what-is-a-word-wall/

Erinn L. Henrichs, B. S. (2011). Interactive Word Walls and Student Perceptions of Vocabulary (Thesis). San Marcos: Texas State University.

Gunning, T. G. (2000). Creating Literacy Instruction for All Children . Boston: Allyn and Bacon .

Hanson, S., \& Padua, J. F. (2011). Teaching Vocabulary Explicitly . U.S.: Pasific Resources for Education and Learning.

Nation, P., \& Newton, J. (1997). Teaching Vocabulary . Cambridge: Cambridge University Press.

Nunan, D. (1991). Second Language Teaching and Learning. Boston: International Thomson Publisher Company.

Nunan, D. (2003). Practical English Language Teaching. McGraw-Hill Education.

Reiser, R. A. (1996). Instructional Planning: A Guide For Teacher. USA: Library of Congress Catalogin Publication Data.

Richards, J. C., \& Renandya, W. A. (2002). Methodology in Language Teaching: An Anthology of Current Practice. New York: Cambridge University Press.

Singh, Y. K. (2006). Fundamental of Research Methodology and Statistics. New Delhi: New Age International Publisher.

Wordwall Create better lessons quicker. (n.d.). (Visual Education Ltd) Retrieved November 30, 2020, from https://wordwall.net/: https://wordwall.net/ 